\title{
Corporate Reputation and Customer Brand Switching Behavior in Sri Lankan Telecommunication Industry
}

\author{
S. G. W. K . Jayawickramarathna \\ Department of Marketing Management, Faculty of Commerce and Management Studies, \\ University of Kelaniya, Sri Lanka \\ wasana@kln.ac.lk
}

\begin{abstract}
In the fiercely competitive telecommunication industry in Sri Lanka, companies tend to focus on the respective customer base without just limiting to the new customers. In this competition, the existing customers are exposed to variety of offers from the competing firms and this may be a persuasive message for the customer to switch the service provider. The corporate reputation of a company can provide a competitive edge to ensure the growth and the survival in a highly competitive environment. This study attempts to assess the impact of corporate reputation on customers brand switching behavior. The study sampled 350 individual customers who have been using the mobile service at a minimum of one year. The data were collected using self-administered questionnaires. The study found that the direct impact of firms' corporate reputation on customers brand switching behavior is significant while some of the major components of corporate reputation are with a greater contribution. Among the determinants of the corporate reputation the emotional appeal and the products and services play a large role in building the customers perception towards the corporate reputation of a firm that will lead to the switching behavior. The firm's corporate reputation could help the marketability of its products or services and it also trigger the positive perception of quality and value of products or services in the mind of their potential customers. The findings of this study provide important implications to the telecommunication operators in their effort to increase their customer base and, more importantly, to ensure the interest of the customers towards the organization.
\end{abstract}

Keywords: Corporate reputation, Emotional appeal, Switching behavior

\section{Introduction}

Companies develop a good general reputation when they consistently engage in strategic actions that produce valuable outcomes that are recognized by customers (Clark \& Montgomery, 1998; Rindova et al., 2007). Fombrun (1996) defined corporate reputation as “a perceptual representation of a company's past actions and future prospects that describes the firm's overall appeal to all of its constituents when compared with other leading rivals. A good reputation increases the predictability of a company's 
behavior and reduces the perceived uncertainty of buyers even in the absence of direct experience with the organization. As a result, customers are willing to exchange resources with the company at a premium, and the highly regarded company has incentives to maintain its good reputation. Therefore, corporate reputation is an attribute or a set of attributes ascribed to a company and inferred from its past actions. It is the belief of market participants about an organization's strategic character (Weigelt \& Camerer, 1988).

Reputation is becoming especially critical today as the public become more aware of events taking place in the marketplace. Customers are the major revenue drivers for a company and their perceptions about a company greatly affect perceptions about a company's reputation. Further, customers' experiences greatly affect other stakeholders' views about a company. Customers have personal experience with a company. The nature of their experience with a company entails that customers deal with company products and services, in addition to possibly dealing with company representatives, online services and other related and auxiliary services. Their direct interactions with a company greatly affect their perceptions about a company.

Further, as a result of the highly competitive landscape, customers are becoming more demanding than ever before. Their expectations go beyond the focus on the core product or service being delivered. They demand higher levels of customer service, product innovations, empathy, payment options, warranties and guarantees which put further pressure on companies to provide competitive product offerings. Thus, understanding and sustaining long-term relationships with customers is important for a company's reputation and survival in the competitive marketplace.

Sri Lankan telecommunication industry has a massive competition and the players strive to keep their customers while attracting new customers to increase their customer base. Companies tend to carry out promotions which enhance their reputation and persuade customers to switch among the service providers which offer similar benefits. In Sri Lanka, customers are more likely to switch among the service providers for these comparative benefits provided. However, the reputation of a company also 
represent as a prominent proportion under switching decision which encourage companies to build and maintain a corporate reputation.

This study explores the impact of corporate reputation on the switching behavior of the consumers in the mobile telecommunication industry in Sri Lanka. The dimensions of corporate reputation is analyzed against the switching behavior of the consumers considering a new area of research as most of the past researchers (Ghose, A., Ipeirotis, P.G. and Sundarajan, A. (2009), Tan, H. (2007) were based upon studying company performances against corporate reputation.

\section{Research Problem}

In modern highly competitive marketing environment, the existing customers as well as potential customers are heavily exposed to various advertising messages from the competing firms through all sorts of media communication. The mobile telecommunication customers in Sri Lanka are facing difficulty in selecting the most reliable service provider for their needs since the range of products and services offered by the competing firms are almost similar in nature. The existing customers of a service provider are encouraged to switch their service to the competing firm by offering certain incentives. Among the incentives offered to the switchers are switching benefits, price reduction, flexible service, and attractive package (Zainudin $\mathrm{Hj}$ Awang, 2009). The existing customers who qualify to enjoy price reduction through loyalty programs would probably stay put with their current service provider. However, those who do not enjoy loyalty incentives offered due to certain reasons as well as potential customers would always be looking for the best service provider for them. Certainly, there are service providers which would feel threatened that their customer base could be affected by the persuasive offer. These firms, in turn, would design their own loyalty programs in order to retain their customer base, and at the same time would launch their own switching incentives to attract customers of other service providers into their service. In the end, customers are being exposed to various offers and counter offers from these competing service providers.

Fombrun and Riel (2003) describe reputation as something that attracts people to an organization like a magnet. As they see it, an organization with a good reputation attracts 
people to engage with it, either through purchasing, investing, working, etc. In other words, they seek to have a relationship with the organization. To "acquire a reputation that is positive, continuing, and flexible requires managers to invest heavily in building and maintaining good relationships with their company's customers" (Fombrun, 1996).

The telecommunication industry in Sri Lanka as an overview indicates that the basic three categories of enterprises in the industry, i.e. the voice, data and managed services category will grow at a constant annual growth rate of $13.8 \%$ and $23.8 \%$ and $22.4 \%$ respectively (Table 1). The voice category includes the wire line, fixed wireless and the GSM facilities provided by the firms whereas the data category consists with basically, IT and Internet services. Managed services represent the services such as managed network, managed security and data centers etc...

\section{Table 1: Consumer market overview}

\begin{tabular}{lccc}
\hline \multicolumn{1}{c}{ Solutions } & $\mathbf{2 0 0 7}$ & $\mathbf{2 0 1 3}$ & CAGR \\
\hline Voice & 309.4 & 673.4 & $13.8 \%$ \\
\hline Data & 54.2 & 195.2 & $23.8 \%$ \\
\hline Managed Services & 47.2 & 158.9 & $22.4 \%$ \\
\hline Total & $\mathbf{4 1 0 . 8}$ & $\mathbf{1 , 0 2 7 . 5}$ & $\mathbf{1 6 . 5 \%}$ \\
\hline
\end{tabular}

Note: All figures are in Mn USD; CAGR: 2007-2013

Source: Frost \& Sullivan estimates

The consumer market overview indicates an annual constant growth rate of $16.6 \%$ in voice category and $36.3 \%$ in data (Internet) category. This is due to the expectation of the market change backed by the customers' interest towards the internet services in future than depending on the voice category. Yet the voice category remains with the larger market share than the data category due to the expanded market opportunities for the players in the industry. 


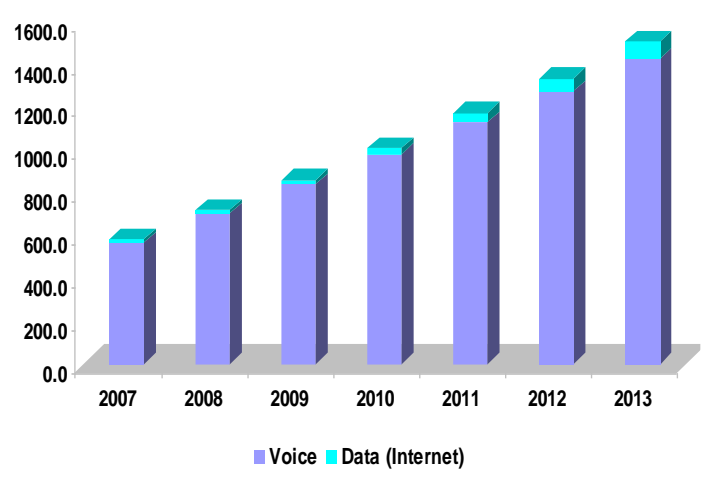

Figure 1: Growth in voice and data market

Note: All figures are in Mn USD; CAGR: 2007-2013

Source: Frost \& Sullivan estimates

Table 2: Growth in consumer market

\begin{tabular}{lccc}
\hline Solutions & $\mathbf{2 0 0 7}$ & $\mathbf{2 0 1 3}$ & CAGR \\
\hline Voice & 568.3 & $1,429.0$ & $16.6 \%$ \\
\hline Data (Internet) & 12.6 & 81.1 & $36.3 \%$ \\
\hline Total & $\mathbf{5 8 0 . 9}$ & $\mathbf{1 , 5 1 0 . 1}$ & $\mathbf{1 7 . 3 \%}$ \\
\hline
\end{tabular}

Note: All figures are in Mn USD; CAGR: 2007-2013

Source: Frost \& Sullivan estimates

Due to this high competition at the mobile telecommunication industry in Sri Lanka, customers are more exposed to persuasive messages from the players in the industry as these companies target the total customer base rather than the new customers. In such a scenario, all competitive firms are trying to keep their own reputation in the market by offering plentiful benefits to the customers. The reputation of a firm could provide a competitive advantage ensuring the survival of the business in the future among the highly competitive environment.

Therefore the players in the industry always strive to achieve a considerable level of corporate reputation as they have identified it as an important element in keeping customers with the company. This creates the importance of investigating how this 
impact has led the Sri Lankan telecommunication customers in deciding their buying behaviors. Yet, there is a problem of identifying how important this concept for a company is. This creates the main aim of this study; to identify how far the corporate reputation can have an influence on the brand switching behavior of the customers. With this background, the problem for this study can be defined as 'To what extent corporate reputation influence on brand switching behavior of customers in the Sri Lankan mobile telecommunication market?'

\section{Objectives of the Study}

The objectives of the study are;

i. To assess the direct influence of corporate reputation of a firm on its customers' brand switching behavior

ii. To understand the individual impact of the key determinants of corporate reputation on brand switching behavior

iii. To suggest how the corporate reputation of a company can be used strategically to gain a competitive advantage in a highly competitive environment

\section{Literature Review}

Corporate reputation is a feature or a set of features attributed to a company and created from the company's past actions. It is the trust of market participants about a company's strategic appeal (Weigelt \& Camerer, 1988). On the other hand, corporate reputation is the public's increasing conclusion about the company over time (Roberts and Dowling, 2002). Some other researchers discussed about corporate reputation as a history of customer perception about the company (Rao, 1994; Rindova and Kotha, 2001).

Yoon, et al. (1993) stated that the proposition of a company's reputation and its service offering information collectively decide a customer's expectations. They found evidence to support the view that a customer's response to a service depends on attitude toward the company's reputation. Nguyen and Leblanc (2001) through their study on reputation tested the nature of the connection between corporate reputation and corporate 
image and their effect on customers' retention decisions and found that the degree of customer loyalty has a trend to be higher when perceptions of both corporate reputation and corporate image are intensely favorable. Moreover, the corporate reputation literatures discovered that competing businesses offering similar range of products and services could differentiate themselves from their competitors and could enjoy certain competitive advantage by positioning their valuable resources and competences that are advanced, uncommon, and unique (Roberts and Dowling, 2002).

Fombrum (1996) stressed that a good corporate reputation would enhance profitability because reputation would attract customers to products, investors to securities, and employees to do their jobs well. Meanwhile, Gupta (2002) found the empirical evidence between corporate reputation and competitive advantage for the firms by successfully differentiating it from competitors.

Fombrun et al. (2000) developed the Reputation Quotient (RQ), a multi-dimensional approach composed of six dimensions that identified stakeholders' perceptions about the reputation of a company. Helm (2005) developed another measure for corporate reputation that was composed of ten elements including ; quality of products; commitment to protecting the environment; corporate success; treatment of employees; customer orientation; commitment to charitable and social issues; value for money of products; financial performance; qualification of management; and credibility of advertising claims.

Since 2000, the Reputation Institute has studied the reputations of over 200 companies based on interviews with over 100,000 people using the RQ instrument in the US and Australia, as well as in other countries and regions. The results indicate that the $\mathrm{RQ}$ is a valid instrument for measuring corporate reputations and can be used to benchmark companies across industries and countries. Hence the same approach is used in this study as the measurement of corporate reputation of companies.

This measurement of reputation enables the identification of critical success factors for corporate reputation from the points of view of different stakeholder groups. Respondents are asked to estimate 20 attributes in six key dimensions (emotional impact, 
products and service, vision and leadership, working environment, financial reward, social responsibility; see figure below).

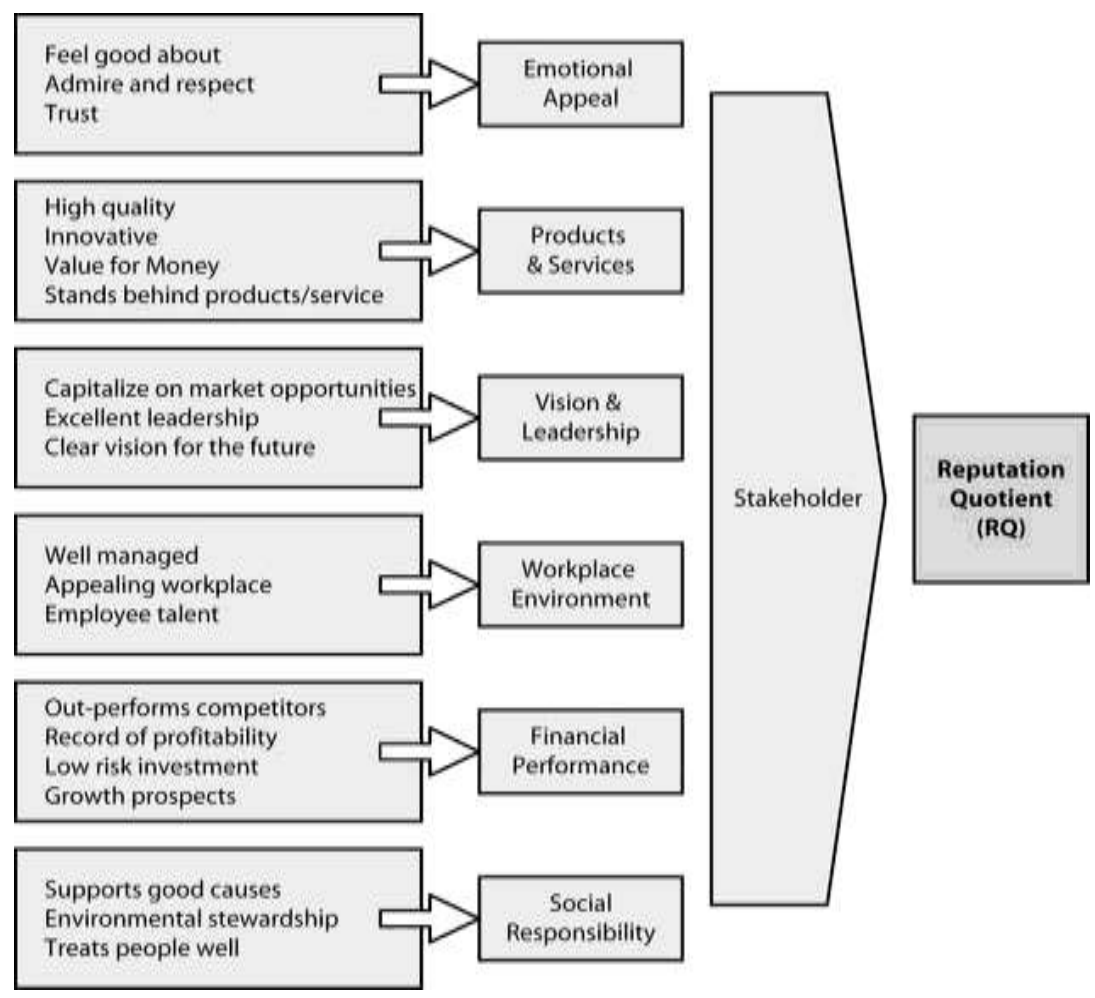

\section{Figure 2: Reputation Quotient (RQ)}

Source: Wiedmann, Fombrun, Riel (2000)

The RQ remains to be one of the most common measures for corporate reputation that is accepted and used by researchers. It has been tested for validity and reliability. Some studies have assessed the perspective of customers when examining corporate reputation, e.g. Walsh and Beatty (2007), others have assessed the perspective of employees, Davies et al. (2004), assessed the perspective of investors. While these studies are important in research, yet there is a need to examine the difference and similarity between primary and secondary stakeholder groups. Accordingly, this research paper offers a more comprehensive overview about corporate reputation by examining the perceptions of customers, who are primary stakeholder groups. 
As reputation said to be a definite competitive advantage for a company, it play a considerable role in convincing customers about the business and the attracting new and the existing customers of the competitors. Switching among rivalry companies is supported and persuasive via the reputation built within the operations of the business. Roos (1999) differentiates three factors of switching decisions using the Switching Path Analysis Technique (SPAT): pushing factors (the reason to switch to another supplier), pulling factors (factors that motivate the customers to come back to the original supplier) and sawyers (they do not cause switching by themselves; they can only moderate or reinforce the switching decision). In the same line, Bansal et al. (2005) establish a model of customers' switching behavior that identifies the process by which customers decide to switch service providers. Similar to Roos (1999), they distinguish push, pull and mooring variables that are central to the switching process. Roos et al. (2004) extend this area of research by analyzing the differences in such processes between five different service industries, showing the differential impact of the determinants identified in function of the industry structure.

Ganesh et al. (2000) in the financial services sector shows that switchers differ from stayers in aspects such as satisfaction, involvement and loyalty. Further, according to Groenland (2002), a positive corporate reputation has a positive influence on consumer trust in the respective company. With regard to customers, previous studies suggest that corporate reputation exerts an influence on perceived risk (Lantos, 1983), and loyalty (Roberts and Dowling, 2002), all of which can positively or negatively affect firm profits.

Literature illustrate that the concept of corporate reputation has been studied under different macro aspects by studying the relationship with the corporate performance of the company. According to Aquevegue and Ravasi (2006), corporate reputation research has "increasingly been capturing the attention of academics in the fields of strategy, economics and management". Reputation as an asset, its impact on switching behavior of the customers is the distinguishing theme of this research. This study therefore discusses how the customers consider the corporate reputation to make brand switching decisions. 


\section{Methods}

Based on the review of literature, the variables under corporate reputation was identified based on the reputation quotient which introduced by Fombrun (2000). Accordingly hypotheses for the study were developed based on each of the variable under the reputation quotient and corporate reputation as the seventh hypothesis to be significantly related with the switching behavior.

$\mathbf{H}_{1}$ : The emotional appeal of a firm has a significant impact on the brand switching behavior of the customers

$\mathbf{H}_{2}$ : The customers' evaluation towards products and services has a significant impact on the brand switching behavior

$\mathbf{H}_{3}$ : The clear vision and the leadership structure of a firm has a significant relationship with the brand switching behavior of the customers

$\mathbf{H}_{4}$ : The workplace environment of the firm has a significant influence on the brand switching behavior of the customers

H5: The financial performance of a firm has a significant relationship with the customers brand switching behavior

H6: The customers' evaluation on the firm's social responsibility has a significant influence on the switching behavior

$\mathbf{H}_{7}$ : Corporate reputation has a significant influence on the customers brand switching behavior

The Figure 3 shows the variables with the related hypotheses developed. 


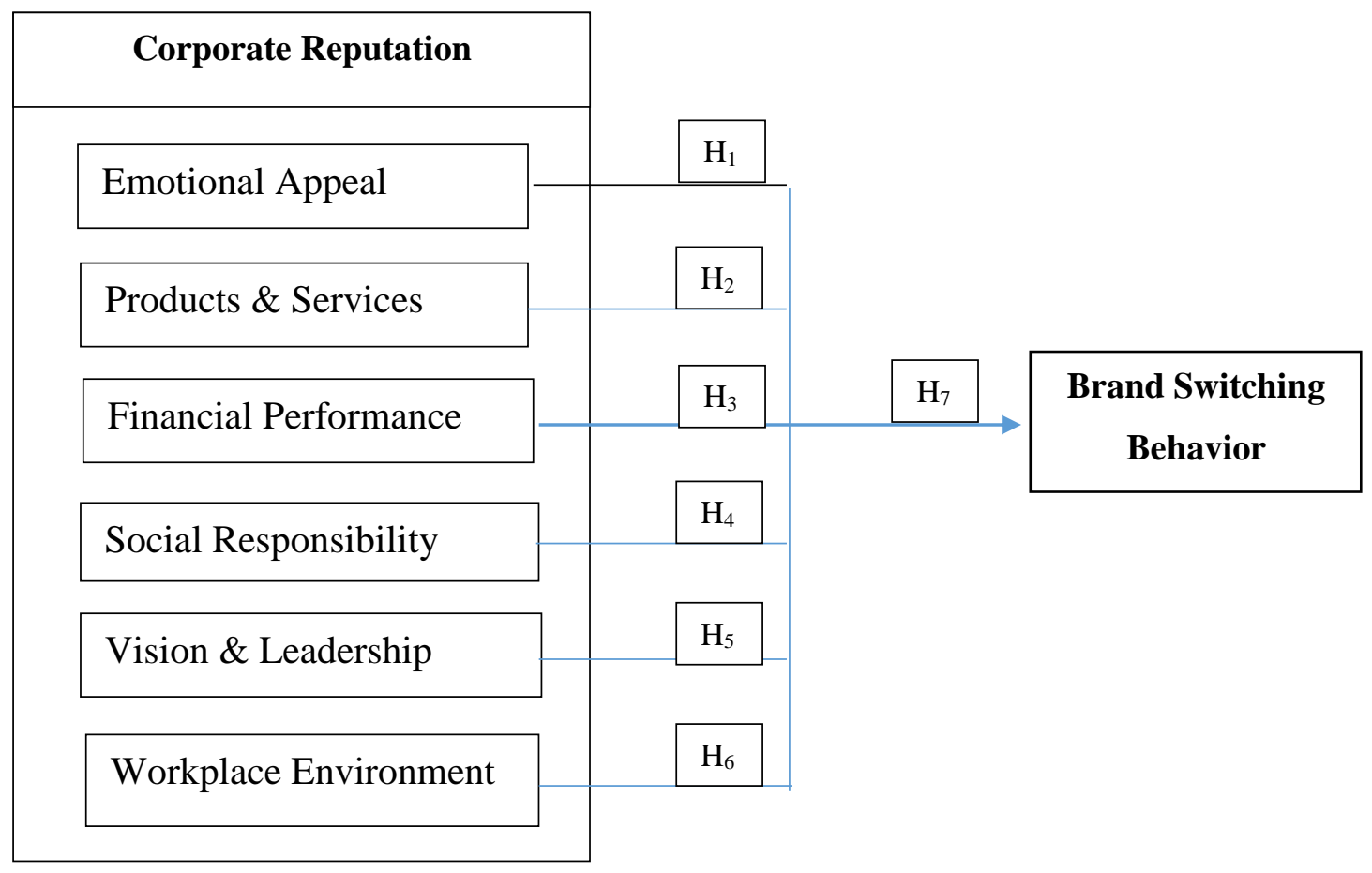

Figure 3: Research Framework

This study is an empirical and needed both primary and secondary data. Therefore, the study was conducted through the sample survey. Data was gathered through self-administrated questionnaire among selected sample respondents. Secondary data was collected through textbooks, articles of journals, web sites and research findings of Frost \& Sullivan on customer survey in telecommunication industry etc. The questionnaire was prepared with using five point Likert scale to get the sample respondents response on the impact of corporate reputation on switching behavior. All questions in questionnaire were structured in accordance with the identified variable represented in the conceptual framework. The samples respondents were selected based on the judgment sampling method due to the representation.

The selected sample consisted of customers who have obtained the service from their respective firm for more than one year. Because, during the time, they have experienced the service provided by their firm, they have heard about the service provided by the competing firms through friends, families, and media. They also have 
been exposed by various advertisements offers either from their own firm or from the competing firms. The study obtained a sample of 350 customers who live in Western province of Sri Lanka. The sample represented $59 \%$ of males and $41 \%$ of females and $75 \%$ of the total sample represented the age category of $20-40$ years. More than $50 \%$ of the sample respondent's income was fallen on the above Rs.30,000 limit.

\section{Findings}

\subsection{Reliability}

Cronbach's coefficient alpha was computed to test for reliability extracting the first 30 respondents' data (Table 01). As a standard mechanism it is suggested to have a minimum of 0.6 Cronbach's Alpha for early stages of research to assess its reliability (Nunnally, 1967). Therefore the constructs were deemed to have adequate reliability to continue with the data analysis.

\section{Table 03: Measures of Reliability}

\begin{tabular}{lcc}
\hline \multicolumn{1}{c}{ Variable } & Cronbach's Alpha & N of Items \\
\hline Emotional appeal & .724 & 2 \\
Products and services & .754 & 3 \\
Financial performance & .753 & 3 \\
Vision and Leadership & .883 & 2 \\
Work place environment & .752 & 3 \\
Social Responsibility & .648 & 2 \\
\hline
\end{tabular}

In analyzing the relationship between the corporate reputation and brand switching behavior, the dimensions have identified through the reputation quotient as discussed under literature review (i.e. Emotional appeal, products and services, vision and leadership, financial performance, workplace environment and social responsibility). Each of these variables were tested in the scale for its mean and the given result (Table 4) shows that there is a positive impact from each of these variables on the brand switching behavior as each provides a value greater than the average. The highest 
significant variables were highlighted as the products and services offered by a company and the emotional attachment of the company with its customers.

Table 04: The mean value of the variables under reputation quotient

\begin{tabular}{lc}
\hline Variable & Mean Value \\
\hline Emotional appeal & 3.78 \\
Products and services & 3.79 \\
Financial performance & 3.63 \\
Vision and Leadership & 3.68 \\
Work place environment & 3.54 \\
Social Responsibility & 3.66 \\
\hline
\end{tabular}

\subsection{Hypotheses Testing}

Hypotheses were tested based on the correlation analysis conducted for each of the variables under corporate reputation with the brand switching behavior. Results indicates that (as shown in table 05 below) other than the vision and leadership variable all the other variables (emotional appeal, products and services, workplace environment, financial performance, social responsibility) show a positive significant correlation with the switching behavior.

Table 05: Correlation between variables under corporate reputation and switching behavior

\begin{tabular}{lc}
\hline Variable & $\begin{array}{c}\text { Person Correlation with } \\
\text { the switching behavior }\end{array}$ \\
\hline Products and services & $.549 * *$ \\
Financial performance & $.721 * *$ \\
Vision and Leadership & .099 \\
Work place environment & $.177 * *$ \\
Financial performance & $.166^{* *}$ \\
Social Responsibility & $.172 * *$ \\
\hline$* *$ Correlation is significant at the 0.01 level (2- tailed)
\end{tabular}


The overall measure of the final hypothesis $\left(\mathrm{H}_{7}\right.$ : Corporate reputation has a significant influence on the customers brand switching behavior) between the corporate reputation and the brand switching behavior of the consumers also resulted in a positive significant relationship as shown in the following table.

Table 6: Relationship between Corporate reputation and brand switching behavior

\begin{tabular}{|ll|r|r|}
\hline & $\begin{array}{r}\text { Switching } \\
\text { behaviour }\end{array}$ & $\begin{array}{c}\text { Corporate } \\
\text { reputation }\end{array}$ \\
\hline Switching & Pearson Correlation & 1 & $.249^{\star *}$ \\
behaviour & Sig. (2-tailed) & & .000 \\
& $\mathrm{~N}$ & 350 & 350 \\
\hline Corporate & Pearson Correlation & $.249^{\star *}$ & 1 \\
reputation & Sig. (2-tailed) & .000 & 350 \\
& $\mathrm{~N}$ & 350 & 350 \\
\hline
\end{tabular}

${ }^{* *}$. Correlation is significant at the 0.01 level (2-tailed).

Through the demographic analysis it was shown that the acceptance of the corporate reputation as a measure on the brand switching behavior is most common for the young age customers as almost $82 \%$ of the customers who were the respondents of this study are at the age 20 to 40 . The study also concluded that the males have more concern on the emotional appeal of the service organization in making the decisions on the service organization than the females. However relating this to the products and services gave the result that the both the gender have the same consideration on the quality of the service offered by the service organization.

\section{Conclusion and Recommendations}

Corporate reputation is the overall estimation in which an organization is held by its internal and external stakeholders based on its past actions and probability of its future behavior. The organization may have a slightly different reputation with each stakeholder according to their experiences in dealing with the organization or in what they have heard about it from others. Among the stakeholder group for the marketers, customer becomes the most important party as they always engaged dealing with the customers. 
The study concluded that the corporate reputation carries a significant relationship with the customers brand switching behavior. Therefore the need of building and maintaining good corporate reputation would be an added advantage for the organizations. Considering the major determinants of the corporate reputation, in Sri Lankan context, showed that emotional appeal and the products and services were more important than the other variables. Hence service organizations should try to build their corporate reputation by improving the relationship of the customers as a bound to emotionally attract the customers to the organizations. As well organizations should always strive to offer a quality product which offers a value for the money they invest. In the telecommunication industry customers switch among the brands records more often. They always tend to compare the value they are getting that of with the competitors. Thus it is important to have the attention on the quality of the products in order to attract and retain the customers with the company.

The investment made on building corporate reputation would obviously provide a long term advantage for the organization as it offers long term benefits compared to other investments. Especially in the telecommunication industry, once the customers have used to the service obtained from a particular service provider they tend to keep the relationship with it for a longer period as they emotionally create a relationship with the organizations. Yet there is a likelihood that these customers would switch the service provider due to the offers made by the competitors in their effort in building the reputation.

The findings from this research provide practical implications for managers at the corporate level. The significance of employee environment as the most important component of corporate reputation highlights the value of investing in training, motivating and the internal marketing of corporate reputation. Employees have an important role toward developing and maintaining a company's reputation. They help in creation of word-of- mouth communications about a company and they contribute significantly to supporting and communicating a company's reputation. Products and services remain to be an important source of reputation that is relevant to both customers 
and the general public. Managers should emphasize their product differentiation elements in their corporate communications programs.

The management's job in achieving favorable corporate reputation for their firm is one issue, but communicating the favorable corporate reputation to customers is another struggle. In here, the management should not try mere achieving a favorable level of corporate reputation for their business but how to communicate their favorable corporate reputation so that the business could enjoy the benefits in the form of competitive advantage. "If customers are to feel and act positively towards a company, it will be in reciprocation for that company making a contribution to their lives". (Lewis, 2001) Therefore managing corporate reputation would provide so many advantages over the company depicting that it is an important strategic and valuable asset a company can possess.

\section{References}

Clark, Bruce H. and David B. Montgomery (1998), "Deterrence, reputations, and Competitive Cognition,” Management Science, January 1998

Fombrum, C. (1996). Reputation. Harvard Business School Press, Boston.

Fombrum, C.J., Gardberg, N. and Sever, J.M. (2000). "The reputation quotient: A multistakeholder measure of corporate reputation". The Journal of Brand Management, 2000

Gupta, Shruti. (2002). "Strategic dimensions of corporate social responsibility as sources of competitive advantage via differentiation". Doctoral Dissertation, Temple University, USA

Helm, S. (2007), “One reputation or many? Comparing stakeholders' perceptions of corporate reputation", Corporate Communications: An International Journal, Vol. 12

Known: An Empirical Examination of the Dimensions, Antecedents and Consequences of Organizational Reputation', Academy of Management Journal, 2007 
Nguyen, N., and Leblanc, G. (2001). "Corporate image and corporate reputation in consumers' retention decision in services". Journal of retailing and Consumer Services, 2001

Nunnaly J.C., (1967), Psychometric theory, New York, McGraw-hill

Rindova, V. P., Williamson, I. O., Petkova, A. P. and Server, J. M. (2007) 'Being Good or Being

Roberts, P.W. and Dowling, G.R. (2002). "Corporate reputation and sustained superior financial performance”. Strategic Management Journal, 2002

Weigelt K., Camerer C., "Reputation and corporate strategy: A review of recent theory and applications", Strategic Management Journal, 1998

Yoon, E., Guffey, H.J. and Kijewski, V. (1993). "The effects of information and company reputation on intentions to buy a business service". Journal of Business Research, 1993

Zainudin, A. (2009). "The influence of Service Quality and Corporate image on Students' Loyalty in Higher Education: The case study of a local university", $\mathrm{PhD}$ Thesis, Universiti Malaysia Terengganu, Malaysia.

Zainudin, A, Azahar, Y, and Masayu, F. (2008). "The influence of corporate reputation on competitive advantage to the firms in household furniture industry". Paper presented at The International Furniture Conference IFCX, PWTC Kuala Lumpur, July 2008 